\title{
Offsetting effects of aerosols on Arctic and global climate in the late 20th century
}

\author{
Q. Yang ${ }^{1,2}$, C. M. Bitz ${ }^{1}$, and S. J. Doherty ${ }^{2}$ \\ ${ }^{1}$ Department of Atmospheric Sciences, University of Washington, Seattle, WA, USA \\ ${ }^{2}$ Joint Institute for the Study of Atmosphere and Ocean, University of Washington, Seattle, WA, USA
}

Correspondence to: Q. Yang (qyang@ atmos.washington.edu)

Received: 29 September 2013 - Published in Atmos. Chem. Phys. Discuss.: 27 November 2013

Revised: 24 March 2014 - Accepted: 25 March 2014 - Published: 22 April 2014

\begin{abstract}
We examine the impacts of atmospheric aerosols on Arctic and global climate using a series of 20th century transient simulations from Community Climate System Model version 4 (CCSM4). We focus on the response of surface air temperature to the direct radiative forcing driven by changes in sulfate and black carbon (BC) concentrations from 1975 to 2005 and we also examine the response to changes in sulfate, $\mathrm{BC}$, and organic carbon (OC) aerosols collectively. The direct forcing from sulfate dominates the aerosol climate effect. Globally averaged, simultaneous changes in all three aerosols produce a cooling trend of $0.015 \mathrm{~K} \mathrm{decade}^{-1}$ during the period $1975-2005$. In the Arctic, surface air temperature has large spatial variations in response to changes in aerosol concentrations. Over the European Arctic, aerosols induce about $0.6 \mathrm{~K} \mathrm{decade}^{-1}$ warming, which is about $1.8 \mathrm{~K}$ warming over the 30 -year period. This warming is triggered mainly by the reduction in sulfate and BC emissions over Europe since the 1970s and is reinforced by sea ice loss and a strengthening in atmospheric northward heat transport. Changes in sulfate concentrations account for about two thirds of the warming and $\mathrm{BC}$ for the remaining one third. Over the Siberian and North American Arctic, surface air temperature is likely influenced by changes in aerosol concentrations over Asia. An increase in sulfate optical depth over Asia induces a large cooling while an increase in BC over Asia causes a significant warming.
\end{abstract}

\section{Introduction}

The Arctic (the region poleward of $60^{\circ} \mathrm{N}$ ) has warmed dramatically since the $1970 \mathrm{~s}$, by $\sim 1.5^{\circ} \mathrm{C}$. The warming in the Arctic is at least two times larger than the global mean temperature increase (e.g., Serreze et al., 2009). This phenomenon is known as Arctic amplification (e.g., Manabe and Stouffer, 1980). The detailed mechanisms causing the warming are not fully understood (Serreze and Barry, 2011). Climate model simulations have shown that ice-albedo feedback is likely to account for much of the Arctic warming (e.g., Holland and Bitz, 2003; Screen and Simmonds, 2010), whereby warmer temperatures cause highly reflective snow and sea ice to melt, decreasing the Earth's planetary albedo and thus inducing further warming. The lapse rate feedback may be equally important (Armour et al., 2013; Pithan and Mauritzen, 2014).

While the feedbacks triggered by greenhouse gas warming may dominate Arctic warming, short-lived aerosols in the atmosphere are also an important forcing agent in this region (e.g., Quinn et al., 2008; Koch et al., 2009a; Shindell and Faluvegi, 2009; Serreze and Barry, 2011). Furthermore, climate changes triggered by aerosol trends will also be enhanced by local feedbacks and modified by circulation changes. Shindell and Faluvegi (2009) conducted sensitivity experiments using the GISS-ER climate model and suggested that decreasing concentrations of sulfate aerosols and increasing concentrations of $\mathrm{BC}$ have substantially contributed to Arctic warming over the last three decades. They also found that Arctic temperature changes depend on the location of $\mathrm{BC}$ in the atmosphere. Increasing concentrations of $\mathrm{BC}$ at low/mid-latitudes cause warming in the Arctic, 
while increasing $\mathrm{BC}$ in the Arctic itself causes cooling in the Arctic. In another climate model study, Sand et al. (2013) produced similar results to Shindell and Faluvegi (2009) and attributed the response in Arctic surface air temperature mainly to the changes in atmospheric northward heat transport (NHT). Increasing atmospheric BC in the Arctic leads to a weakening of NHT and thus surface cooling; when BC is located at mid-latitudes, NHT is strengthened, leading to Arctic surface warming. Arctic surface temperature is also found to be sensitive to the vertical distribution of $\mathrm{BC}$ in the CCSM4 (Flanner, 2013): a layer of BC centered in the upper troposphere produces surface cooling, while a layer of $\mathrm{BC}$ in the lower troposphere causes weak surface warming. While there has been much focus on the role of BC in Arctic climate, we are interested in how Arctic climate has been affected by changes in both sulfate and $\mathrm{BC}$ aerosol distributions over the past three decades. As shown below, trends in the two are not homogenous in either space or time.

Here, the response of Arctic and global surface air temperature to the trends of atmospheric sulfate and $\mathrm{BC}$ aerosols is examined using 20th century simulations from CCSM4. We performed single forcing experiments, in which only direct radiative forcing from sulfate aerosols or $\mathrm{BC}$ was included. This enables us to isolate the effects of sulfate and $\mathrm{BC}$ and their contributions to the effect of all aerosols on climate. We also examine the response to changes in sulfate, $\mathrm{BC}$, and $\mathrm{OC}$ aerosols collectively. In addition to surface air temperature, we investigate the response of sea level pressure, sea ice coverage, cloud radiative forcing and atmospheric NHT to determine the mechanisms that caused the surface air temperature change in the Arctic during the period 1975-2005.

\section{Model and experiments}

We use CCSM4 with fully coupled atmosphere, ocean, land and sea ice components (Gent et al., 2011). The atmosphere component is the Community Atmosphere Model 4 (CAM4) (Neale et al., 2011) with a horizontal resolution of $0.9^{\circ} \times 1.25^{\circ}$. The atmospheric aerosol concentrations were derived from an offline CAM-Chem (Lamarque et al., 2012) driven by observationally based estimates of aerosol emissions (Lamarque et al., 2010, 2011) for the period 18502005 (see below). In the work of Lamarque et al. (2010, 2011, 2012), anthropogenic emissions of sulfur species were an update of Smith et al. (2001, 2004). The oceanic DMS emission was estimated from Kettle et al. (1999). Volcanic and biomass sources of sulfur are excluded (Neale et al., 2011). Emissions of BC and OC represent an update of Bond et al. (2007) and Junker and Liousse (2008). The Mie calculations for sulfate assume that it is comprised of ammonium sulfate with a log-normal size distribution (Neale et al., 2011). BC and OC are assumed to age from hydrophobic to hydrophilic at an e-folding time of 1.2 days. The optics for BC and OC in CAM4 are identical to the optics for soot and water-soluble aerosols in the Optical Properties of Aerosols and Clouds (OPAC) data set (Hess et al., 1998; Neale et al., 2011). Total aerosol optical depth comparisons with AERONET observations indicate a reasonably good simulation (Lamarque et al., 2010). Shindell et al. (2013) used this atmospheric aerosol concentration data set and demonstrated that it captures total aerosol optical depth trends of 1980-2000 well over the areas of high aerosol emissions (e.g., Europe, eastern North America and southern and eastern Asia), compared with Advanced Very High Resolution Radiometer (AVHRR) observations. Compared with high-latitude aircraft campaigns, simulated BC concentrations, using the same emission sources as Lamarque et al. (2010) but with a previous version of CAM, are within the observed standard deviation (Koch et al., 2009b). CAM4 includes the direct and semi-direct effects of aerosols, but the aerosol first indirect effect (Twomey et al., 1984) is not included. The same model and 20th century forcing data sets were used for the Coupled Model Intercomparison Project phase 5 (CMIP5) (Taylor et al., 2012) contributions from CCSM4.

Table 1 lists the details of our individual model experiments. The all-aerosol simulations were realized by varying the time- and space-evolving mass concentrations of sulfate, $\mathrm{BC}$ and $\mathrm{OC}$ aerosols simultaneously. All other forcings were kept fixed at 1850 levels, including surface depositions of $\mathrm{BC}$ on snow and sea ice. A single aerosol species was varied in sulfate-only and BC-only single-forcing experiments, where only the mass concentration of either sulfate or BC was varied, respectively. Three ensemble members of allaerosol simulations plus three ensemble members of sulfateonly simulations in CCSM4 were obtained from the CMIP5 archive (Meehl et al., 2012). In the all-aerosol and sulfateonly simulations that we obtained from CMIP5, the runs were branched from a pre-industrial control. Output from the pre-industrial control run was also obtained from the CMIP5 archive.

New for this study, six branch runs were carried out varying sulfate-only and another six varying BC-only from year 1920 and run to year 2005. The restart files of year 1920 were obtained from 20th century all-aerosol forcing only integrations with CCSM4 that were contributed to CMIP5 (see Meehl et al., 2012).

Figure 1 shows linear trends in optical depths of sulfate and BC from 1975 to 2005 in CCSM4. The results are ensemble means of six integrations. Since the 1970s, sulfate aerosol optical depth has decreased significantly in Europe and North America. However, aerosol optical depth has increased in Southeast Asia, India and the Pacific Ocean region (Fig. 1a). Globally, there is a decrease in sulfate aerosol optical depth (not shown). Due to the emission reductions in Europe and North America, sulfate optical depth has decreased over the Arctic, especially over the Eurasian Arctic (Fig. 1b). Sulfate aerosol is almost entirely scattering, with a single scattering albedo equal to one in the solar spectrum and a small fraction 
Table 1. List of experiments, number of ensemble members, whether the run with CCSM4 was obtained from CMIP5 or is a new run conducted in this study, run period, trend analysis period and aerosols that vary in the run.

\begin{tabular}{|c|c|c|c|c|c|}
\hline $\begin{array}{l}\text { Model } \\
\text { experiment }\end{array}$ & $\begin{array}{l}\text { \# of ensemble } \\
\text { members }\end{array}$ & $\begin{array}{l}\text { CCSM4 runs, from CMIP5 } \\
\text { or new (this study) }\end{array}$ & $\begin{array}{l}\text { Run } \\
\text { period }\end{array}$ & $\begin{array}{l}\text { Trend analysis } \\
\text { period }\end{array}$ & $\begin{array}{l}\text { Aerosols } \\
\text { that vary }\end{array}$ \\
\hline All ae & 3 & CMIP5 & $1850-2005$ & $1975-2005$ & $\mathrm{SO}_{4}, \mathrm{BC}$ and $\mathrm{OC}$ \\
\hline \multirow[t]{2}{*}{$\mathrm{SO}_{4}$-only } & $3^{*}$ & CMIP5 & $1850-2005$ & 1975-2005 & $\mathrm{SO}_{4}$ \\
\hline & 6 & New run & 1920-2005 & $1975-2005$ & $\mathrm{SO}_{4}$ \\
\hline BC-only & 6 & New run & 1920-2005 & 1975-2005 & $\mathrm{BC}$ \\
\hline Pre-industrial control & 1 & CMIP5 & $1250-1300$ & N/A & None \\
\hline
\end{tabular}

${ }^{*}$ Only the surface air temperature field was available.
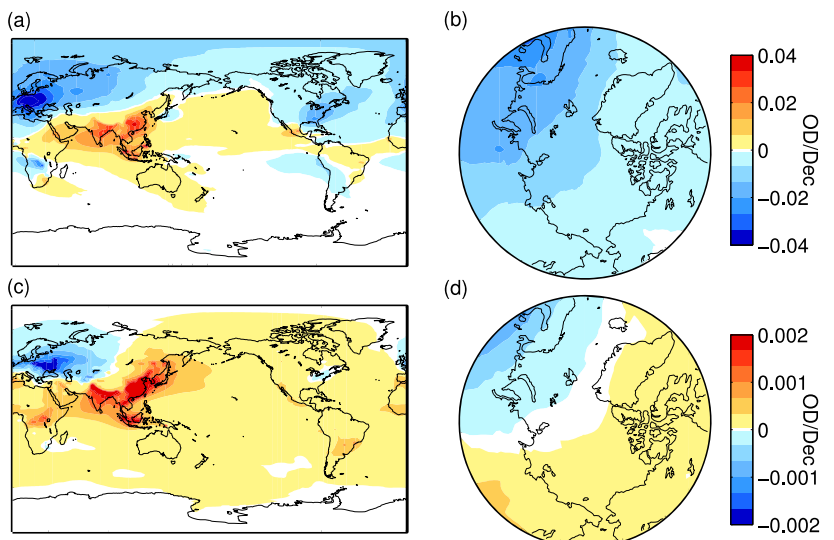

(d)

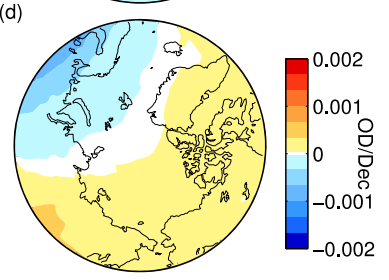

Fig. 1. Linear trends in optical depths per decade for sulfate $(\mathbf{a}, \mathbf{b})$ and black carbon (c, d) for the period 1975-2005, both globally and for the Arctic.

of absorption in the near-infrared spectrum. Therefore, it causes a net radiative cooling at the surface by scattering solar radiation back to space and letting less solar radiation reach the surface (IPCC, 2007, p. 160). The mean surface shortwave radiative flux change in year 2000 due to sulfate is estimated at $-0.84 \mathrm{~W} \mathrm{~m}^{-2}$ globally and $-0.22 \mathrm{~W} \mathrm{~m}^{-2}$ for the Arctic in CCSM4. These estimates were performed by running CAM4 shortwave radiative transfer code twice (once with and once without sulfate aerosols), with adjusted temperatures at all levels each time.

From 1975 to 2005 there were significant reductions in BC optical depth in Europe, but over the same period there were significant increases in optical depth in India and China (Fig. 1c). At the same time, emissions of fossil fuel BC declined in the US (IPCC, 2007, p. 163). Thus, the slight increase in BC optical depth over North America seen in Fig. 1c is possibly due to the downstream transport from Asia. In contrast, there was a decline in sulfate optical depth over North America and over all of the Arctic (Fig. 1a and b). While global mean sulfate emissions declined, $\mathrm{BC}$ emissions increased (Lamarque et al., 2010). In the Arctic, BC optical depth shows a negative trend over the European Arctic but a positive trend over the rest of the Arctic (Fig. 1d).

$\mathrm{BC}$ is a light-absorbing aerosol, so it absorbs solar radiation and heats the surrounding air (IPCC, 2007, p. 163). The annual mean instantaneous flux change at the surface due to the direct effect of atmospheric $\mathrm{BC}$ is $-0.46 \mathrm{~W} \mathrm{~m}^{-2}$ over the whole globe and $-0.14 \mathrm{~W} \mathrm{~m}^{-2}$ over the Arctic in model year 2000 in CCSM4.

\section{Results}

\subsection{Surface air temperature trends}

Figure 2 depicts the time-evolving surface air temperature response to the change in all aerosols, sulfate-only and BConly from 1920 to 2005 . The all-aerosol, sulfate-only and BC-only runs have ensemble members of three, nine and six, respectively (Table 1). Globally, surface air temperature from all-aerosol forcing shows a significant negative trend of about $0.02 \mathrm{~K} \mathrm{decade}^{-1}$ for $1920-2005$ and $\sim 0.015 \mathrm{~K} \mathrm{decade}^{-1}$ for 1975-2005 in CCSM4. This result agrees with the study by Fyfe et al. (2013) that other forcing (primarily aerosol forcing) causes a modest Arctic cooling among CMIP5 models from 1970 to 2005 . Surface air temperature from sulfate-only forcing resembles that of the all-aerosol forcing in CCSM4. Therefore, the response of global surface air temperature to all aerosols is dominated by the direct forcing by sulfate. BC has a warming effect on global temperature $(\sim 0.1 \mathrm{~K})$, but this is almost completely offset by the cooling influence from organic carbon, which is co-emitted with BC (e.g., Bond et al., 2013). In the Arctic, surface air temperature is more variable, with no clear trends in Arctic-averaged surface air temperature from 1975 to 2005 in any of the three cases. The BC-only case indicates some warming from 1980 to 2000, followed by a cooling for 2000-2010, but this is not statistically significant. However, there are statistically significant positive and negative temperature trends in different regions of the Arctic, which in this Arctic-wide average offset each other.

Geographic distributions of surface air temperature trends for 1975-2000 are shown in Fig. 3. We focus primarily on the changes in the Arctic, but show the global maps to aid interpretation of what is driving the Arctic changes. Direct 

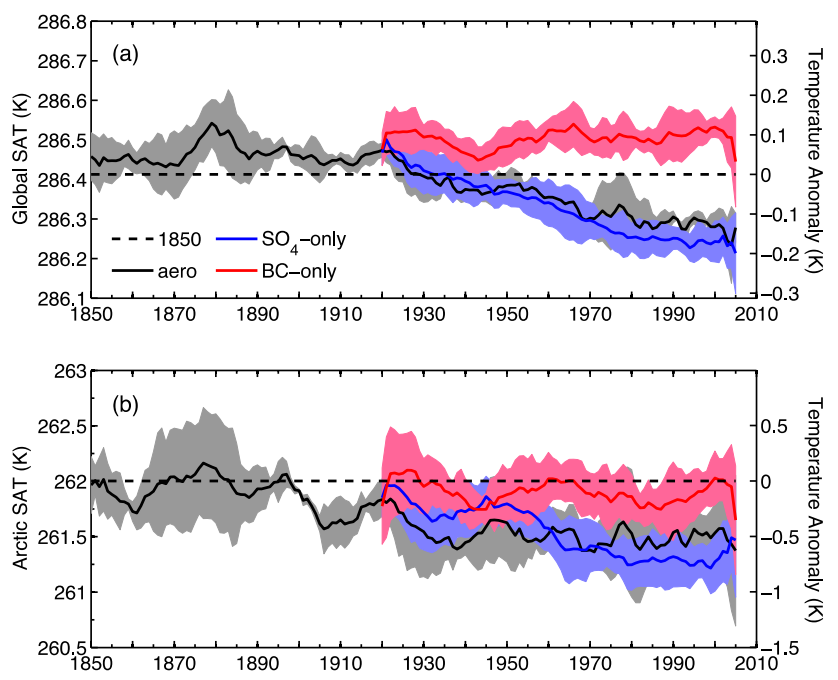

Fig. 2. Time series of area-weighted, annual-mean surface air temperature (SAT) over the globe (a) and Arctic (b) for all aerosol forcing (black), sulfate-only forcing (blue) and BC-only forcing (red). Shading indicates one standard deviation of ensemble members. A 9 -year running mean was applied. A pre-industrial (year 1850) control run is shown in black dashed line.

radiative forcing by all aerosols produces a pronounced warming of $0.6 \mathrm{~K} \mathrm{decade}^{-1}$ over the European Arctic, a cooling of $0.6 \mathrm{Kdecade}^{-1}$ over the Russian Arctic and a slight warming over the North American Arctic (Fig. 3a and b). The pattern of temperature trends in the all-aerosol case has elements in common with both the sulfate-only and BConly cases. In the sulfate-only experiment, there is a strong warming of $0.4 \mathrm{~K} \mathrm{decade}^{-1}$ over the European and western Eurasian Arctic (Fig. 3c and d) where sulfate optical depth has declined (Fig. 1a). In and downstream of Siberia and in the western US there is a significant cooling, which is contrary to what might be expected, given that sulfate concentrations and sulfate optical depth decreased across this region (Fig. 1). Such mismatches in the sign of temperature response and aerosol forcing are not unique to $\mathrm{SO}_{4}$. In $\mathrm{BC}$-only simulations (Fig. 3e and f), surface air temperatures warm $0.2 \mathrm{~K} \mathrm{decade}^{-1}$ over the European Arctic, presumably in response to a reduction in $\mathrm{BC}$ concentrations aloft. There is a pronounced warming of roughly $0.4 \mathrm{~K} \mathrm{decade}^{-1}$ over the Siberian and Alaskan Arctic and a strong cooling over the far North Atlantic despite small increases in BC optical depth in these regions. While there is some correspondence between the change in aerosol optical depths (Fig. 1) and surface air temperatures (Fig. 3), the two are not perfectly correlated. This is because, in addition to the direct impact of aerosols on radiative fluxes, there may be other climate responses to the forcings, which themselves affect surface air temperatures. In some cases, quite long-range connections are possible. Previous studies (Shindell and Faluvegi, 2009; Sand et al., 2013; Flanner, 2013) regarding the role of remote aerosols in Arc-
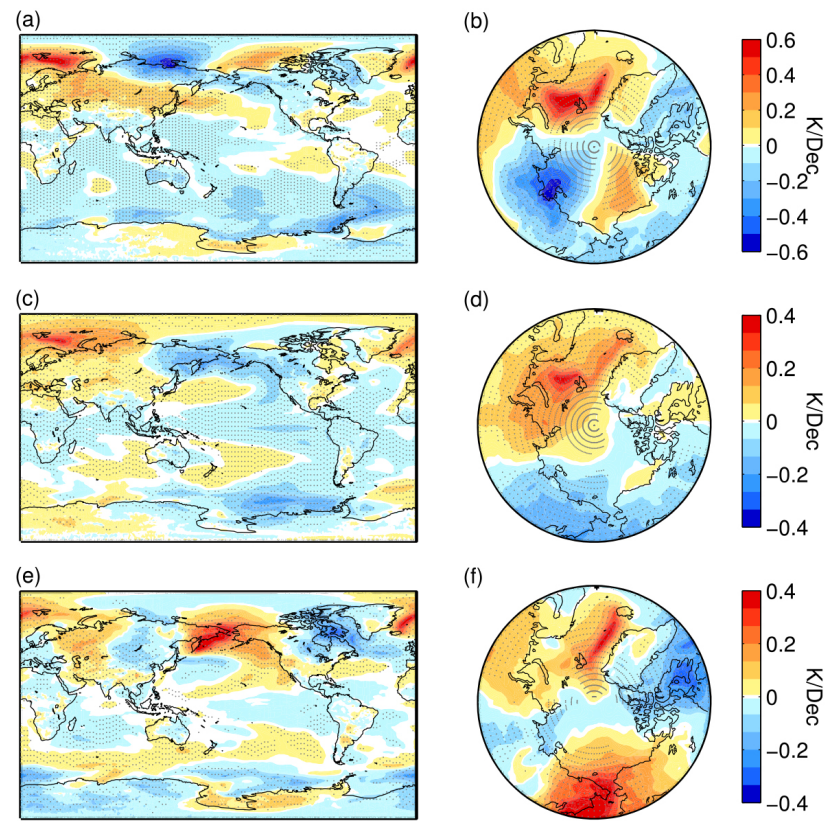

Fig. 3. Linear trends in surface air temperature for the period 19752005 over the globe and Arctic due to changes in all aerosols (a and b), sulfate only (c and d) and black carbon only (e and f), respectively. Gray dots indicate trends that are statistically significant at the $95 \%$ level $(p<0.05)$ based on an $F$ test.

tic temperatures show that an increase in $\mathrm{BC}$ concentrations at low latitudes causes a warming in the Arctic. Such remote influence is also shown by Teng et al. (2012), who found surface warming over the Siberian Arctic in response to increasing BC concentrations in Asia in CCSM4 (see their Fig. 2). We emphasize that these results are specific to CCSM4. As shown in Koch et al. (2009b), general circulation models have great variability in simulating BC aerosols. Even when using a fixed set of emissions, different models will simulate different horizontal and vertical distributions of $\mathrm{BC}$ aerosols, as well as differences in total atmospheric burden. Therefore it is of great interest for future studies to examine the climate response of $\mathrm{BC}$ using different models.

\subsection{Interpreting the climate responses to forcing}

To understand the temperature trends further we analyzed sea level pressure, sea ice coverage, radiative flux changes at top of the atmosphere (TOA) due to changes in clouds and changes in NHT using the transient sulfate-only and BConly runs as described in Sect. 2. NHT is calculated following Eq. (1) in Sand et al. (2012). In the sulfate-only experiment (Fig. 4a-d), there is a dipole in sea level pressure trends, i.e., in the eastern North Atlantic versus in the European and west Eurasian Arctic. This draws warmer air northward from lower latitudes, consistent with the strong warming trend found in the European Arctic. The significant sea ice loss over the Barents Sea amplifies the warming there. Surface 

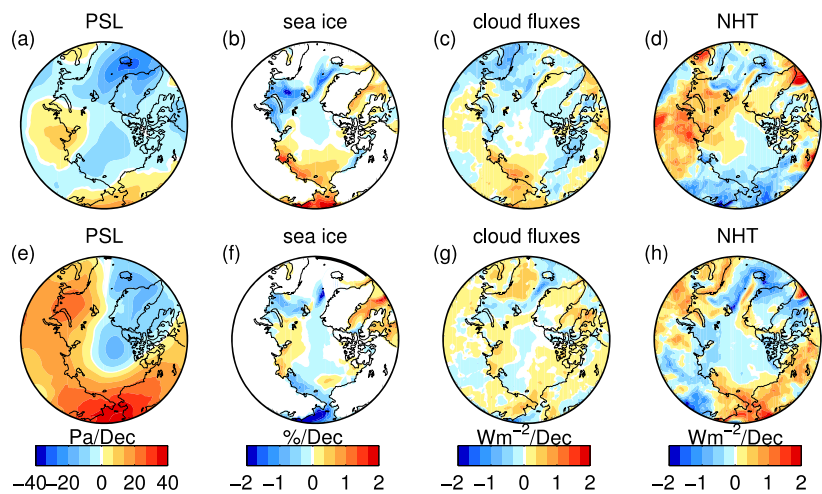

Fig. 4. Linear trends in sea level pressure (PSL), sea ice coverage, cloud net radiative fluxes at top of the atmosphere, and atmospheric northward heat transport (NHT) over the period 1975-2005 in the Arctic due to direct radiative forcing by sulfate only (a, b, $\mathbf{c}$ and $\mathbf{d}$ ) and black carbon only (e, f, $\mathbf{g}$ and $\mathbf{h})$, respectively.

cooling over most of the rest of the Arctic is consistent with cold-air advection from Siberia, amplified by sea ice gain on the Siberian shelf and into the Chukchi and Beaufort seas. Net changes in cloud radiative fluxes at TOA, which are the summation of shortwave and longwave fluxes, have a similar pattern to the changes in sea ice coverage. These show a radiative cooling effect over the European Arctic and warming over Siberia. NHT enhances the warming over the Eurasian Arctic and the cooling over the Siberian and North American Arctic. These findings suggest that direct surface radiative cooling from sulfate aerosols is the possible trigger for the surface cooling while the dynamical response of atmospheric circulation, sea ice, and clouds works together to reinforce such temperature trends. Cloud changes have a weaker influence than sea ice and NHT changes in terms of magnitudes of trends. Again, we emphasize that the cloud changes produced here are only due to a thermodynamic response to the aerosol direct radiative forcing. If cloud microphysical effects were included in the model runs cloud changes might have a much more significant impact on Arctic climate.

The dynamical responses of the atmosphere and sea ice are similarly important in the BC-only experiment (Fig. 4e-h). Sea ice coverage decreases near the Barents Sea and the eastern Siberia shelf, where surface air temperature increases. NHT has strong positive trends over the Eurasian and North American Arctic. Therefore, the responses in both sea ice and NHT to aerosol direct radiative forcing reinforce the surface air temperature changes. Trends in net cloud radiative fluxes are weak and do not show a clear pattern.

\section{Summary and discussion}

We use fully coupled CCSM4 with CAM4 physics to investigate the Arctic and global climate response to the change in concentrations of all aerosols, sulfate aerosols only and
$\mathrm{BC}$ only during the three decades from 1975 to 2005 . Singleforcing transient simulations were performed in order to isolate the impacts of all aerosols, sulfate only and $\mathrm{BC}$ only. The surface air temperature response to all aerosols in CCSM4 is dominated by changes in sulfate, while the effects of $\mathrm{BC}$ are apparently mostly offset by coincident trends in OC. Globally averaged, trends in all aerosols produce a cooling trend of $0.015 \mathrm{~K} \mathrm{decade}^{-1}$ during the period of $1975-2005$, with $0.02 \mathrm{~K} \mathrm{decade}^{-1}$ cooling driven by changes in sulfate aerosols. Averaged across the whole Arctic, surface air temperature shows no significant trend. However, there are pronounced geographical variations in temperature trends. Over the European Arctic, aerosols induce about $0.6 \mathrm{~K} \mathrm{decade}^{-1}$ warming, or about $1.8 \mathrm{~K}$ warming over the 30 -year period from 1975 to 2005 . This warming is triggered by a reduction in sulfate and $\mathrm{BC}$ concentrations over that region and is maintained by sea ice loss and a strengthening in NHT. Changes in sulfate concentrations account for about two thirds of the warming and $\mathrm{BC}$ for the remaining one third. A recent study by Cowtan and Way (2014) shows that global temperature rise of the past 15 years has been largely underestimated due to data gaps, especially in the Arctic. Based on the simulations presented here, we believe that sulfate aerosol trends have played an important role in the Arctic warming and may potentially have prevented the warming "hiatus" seen in global temperature trends (Trenberth and Fasullo, 2013) from occurring in the Arctic temperature trends. Over the Siberian and North American Arctic, surface air temperature is likely influenced by changes in aerosol optical depth over Asia. An increase in sulfate optical depth over Asia induces a large cooling while an increase in BC optical depth over Asia causes a significant warming, consistent with Shindell and Faluvegi (2009). Thus, full understanding of drivers of Arctic climate change requires accounting for changes in all aerosol species - not just $\mathrm{BC}$ - and for the climate responses to both local and remote forcings.

Acknowledgements. We would like to acknowledge high-performance computing support from Yellowstone (ark:/85065/d7wd3xhc) provided by NCAR's Computational and Information Systems Laboratory, sponsored by the National Science Foundation. We acknowledge J. Arblaster and A. Middleton for providing the restart files and CCSM4 sulfate-only runs. We thank L. Mickley, T. Breider, D. Jacob, M. Flanner and two anonymous reviewers for helpful discussions. We acknowledge the World Climate Research Programme's Working Group on Coupled Modelling, which is responsible for CMIP, and we thank the climate modeling groups for producing and making available their model output. For CMIP the US Department of Energy's Program for Climate Model Diagnosis and Intercomparison provides coordinating support and led development of software infrastructure in partnership with the Global Organization for Earth System Science Portals. This study was supported by the National Science Foundation grant ARC-1049002.

Edited by: R. Krejci 


\section{References}

Armour, K. C., Bitz, C. M., and Roe, G. H.: Time-Varying Climate Sensitivity from Regional Feedbacks, J. Climate, 26, 4518-4534, doi:10.1175/JCLI-D-12-00544.1, 2013.

Bond, T. C., Bhardwaj, E., Dong, R., Jogani, R., Jung, S., Roden, C., Streets, D. G., and Trautmann, N. M.: Historical emissions of black and organic carbon aerosol from energy-related combustion, 1850-2000, Global Biogeochem. Cy., 21, GB2018, doi:10.1029/2006GB002840, 2007.

Bond, T. C., Doherty, S. J., Fahey, D. W., Forster, P. M., Berntsen, T., DeAngelo, B. J., Flanner, M. G., Ghan, S., Kärcher, B., Koch, D., Kinne, S., Kondo, Y., Quinn, P. K., Sarofim, M. C., Schultz, M. G., Schulz, M., Venkataraman, C., Zhang, H., Zhang, S., Bellouin, N., Guttikunda, S. K., Hopke, P. K., Jacobson, M. Z., Kaiser, J. W., Klimont, Z., Lohmann, U., Schwarz, J. P., Shindell, D., Storelvmo, T., Warren, S. G., and Zenderm C. S.: Bounding the role of black carbon in the climate system: a scientific assessment, J. Geophys. Res.-Atmos., 118, 5380-5552, doi:10.1002/jgrd.50171, 2013.

Cowtan, K. and Way, R. G.: Coverage bias in the HadCRUT4 temperature series and its impact on recent temperature trends, Q. J. Roy. Meteor. Soc., doi:10.1002/qj.2297, 2014.

Flanner, M. G.: Arctic climate sensitivity to local black carbon, J. Geophys. Res.-Atmos., 118, 1840-1851, doi:10.1002/jgrd.50176, 2013.

Fyfe, J. C., Salzen, K. V., Gillett, N. P., Arora, V. K., Flato, G. M., and McConnell, J. R.: One hundred years of Arctic surface temperature variation due to anthropogenic influence, Sci. Rep., 3, 2645, doi:10.1038/srep02645, 2013.

Gent, P. R., Danabasoglu, G., Donner, L. J., Holland, M. M., Hunke, E. C., Jayne, S. R., Lawrence, D. M., Neale, R. B., Rasch, P. J., Vertenstein, M., Worley, P. H., Yang, Z.-L., and Zhang, M.: The community climate system model version 4, J. Climate, 24, 4973-4991, doi:10.1175/2011JCLI4083.1, 2011.

Hess, M., Koepke, P., and Schult, I.: Optical properties of aerosols and clouds: the software package OPAC, B. Am. Meteorol. Soc., 79, 831-844, 1998.

Holland, M. M. and Bitz, C. M.: Polar amplification of climate change in the coupled model intercomparison project, Clim. Dynam., 21, 221-232, 2003.

IPCC: Climate Change 2007: The Physical Science Basis. Contribution of Working Group I to the Fourth Assessment Report of the Intergovernmental Panel on Climate Change, edited by: Solomon, S., Qin, D., Manning, M., Chen, Z., Marquis, M., Averyt, K. B., Tignor, M., and Miller, H. L., Cambridge University Press, Cambridge, UK and New York, NY, USA, 2007.

Junker, C. and Liousse, C.: A global emission inventory of carbonaceous aerosol from historic records of fossil fuel and biofuel consumption for the period 1860-1997, Atmos. Chem. Phys., 8, 1195-1207, doi:10.5194/acp-8-1195-2008, 2008.

Kettle, A. J., Andreae, M. O., Amouroux, D., and Andreae, T. W.: A global database of sea surface dimethylsulfide (DMS) measurements and a procedure to predict sea surface DMs as a function of latitude, longitude, and month, Global Biogeochem. Cy., 13, 399-444, 1999.

Koch, D., Menon, S., Genio, A. D., Ruedy, R., Alienov, I., and Schmidt, G. A.: Distinguishing aerosol impacts on climate over the past century, J. Climate, 22, 2659-2677, 2009a.
Koch, D., Schulz, M., Kinne, S., McNaughton, C., Spackman, J. R., Balkanski, Y., Bauer, S., Berntsen, T., Bond, T. C., Boucher, O., Chin, M., Clarke, A., De Luca, N., Dentener, F., Diehl, T., Dubovik, O., Easter, R., Fahey, D. W., Feichter, J., Fillmore, D., Freitag, S., Ghan, S., Ginoux, P., Gong, S., Horowitz, L., Iversen, T., Kirkevåg, A., Klimont, Z., Kondo, Y., Krol, M., Liu, X., Miller, R., Montanaro, V., Moteki, N., Myhre, G., Penner, J. E., Perlwitz, J., Pitari, G., Reddy, S., Sahu, L., Sakamoto, H., Schuster, G., Schwarz, J. P., Seland, Ø., Stier, P., Takegawa, N., Takemura, T., Textor, C., van Aardenne, J. A., and Zhao, Y.: Evaluation of black carbon estimations in global aerosol models, Atmos. Chem. Phys., 9, 9001-9026, doi:10.5194/acp-9-9001-2009, 2009b.

Lamarque, J.-F., Bond, T. C., Eyring, V., Granier, C., Heil, A., Klimont, Z., Lee, D., Liousse, C., Mieville, A., Owen, B., Schultz, M. G., Shindell, D., Smith, S. J., Stehfest, E., Van Aardenne, J., Cooper, O. R., Kainuma, M., Mahowald, N., McConnell, J. R., Naik, V., Riahi, K., and van Vuuren, D. P.: Historical (1850-2000) gridded anthropogenic and biomass burning emissions of reactive gases and aerosols: methodology and application, Atmos. Chem. Phys., 10, 7017-7039, doi:10.5194/acp10-7017-2010, 2010.

Lamarque, J.-F., Kyle, G. P., Meinshausen, M., Riahi, K., Smith, S. J., van Vuuren, D. P., Conley, A., and Vitt, F.: Global and regional evolution of short-lived radiatively-active gases and aerosols in the representative concentration pathways, Climatic Change, 109, 191-912, doi:10.1007/s10584-011-0155-0, 2011.

Lamarque, J.-F., Emmons, L. K., Hess, P. G., Kinnison, D. E., Tilmes, S., Vitt, F., Heald, C. L., Holland, E. A., Lauritzen, P. H., Neu, J., Orlando, J. J., Rasch, P. J., and Tyndall, G. K.: CAM-chem: description and evaluation of interactive atmospheric chemistry in the Community Earth System Model, Geosci. Model Dev., 5, 369-411, doi:10.5194/gmd-5-369-2012, 2012.

Manabe, S. and Stouffer, R. J.: Sensitivity of a global climate model to an increase of $\mathrm{CO}_{2}$ concentration in the atmosphere, J. Geophys. Res., 85, 5529-5554, 1980.

Meehl, G. A., Washington, W. M., Arblaster, J. M., Hu, A., Teng, H., Tebaldi, C., Sanderson, B. N., Lamarque, J.-F., Conley, A., Strand, W. G., and White III, J. B.: Climate system response to external forcings and climate change projections in CCSM4, J. Climate, 25, 3661-3683, 2012.

Neale, R. B., Richter, J. H., Conley, A. J., Park, S., Lauritzen, P. H., Gettelman, A., Williamson, D. L., Rasch, P. J., Vavrus, S. J., Taylor, M. A., Collins, W. D., Zhang, M., and Lin, S.- J.: Description of the NCAR Community Atmosphere Model (CAM4), NCAR Tech. Rep. NCAR/TN-485 + STR, 212 pp., available at: https://www.ccsm.ucar.edu/models/ccsm4.0/cam/docs/ description/cam4_desc.pdf (last access: 16 April 2014), 2011.

Pithan, F. and Mauritsen, T.: Arctic amplification dominated by temperature feedbacks in contemporary climate models, Nat. Geosci., 7, 181-184, doi:10.1038/ngeo2071, 2014.

Quinn, P. K., Bates, T. S., Baum, E., Doubleday, N., Fiore, A. M., Flanner, M., Fridlind, A., Garrett, T. J., Koch, D., Menon, S., Shindell, D., Stohl, A., and Warren, S. G.: Short-lived pollutants in the Arctic: their climate impact and possible mitigation strategies, Atmos. Chem. Phys., 8, 1723-1735, doi:10.5194/acp8-1723-2008, 2008. 
Sand, M., Berntsen, T. K., Kay, J. E., Lamarque, J. F., Seland, $\varnothing$., and Kirkevåg, A.: The Arctic response to remote and local forcing of black carbon, Atmos. Chem. Phys., 13, 211-224, doi:10.5194/acp-13-211-2013, 2013.

Screen, J. A. and Simmonds, I.: The central role of diminishing sea ice in recent Arctic temperature amplification, Nature, 464, 1334-1337, 2010.

Serreze, M. C. and Barry, R. G.: Processes and impacts of Arctic amplification: a research synthesis, Global Planet. Change, 77, 85-96, doi:10.1016/j.gloplacha.2011.03.004, 2011.

Serreze, M. C., Barrett, A. P., Stroeve, J. C., Kindig, D. N., and Holland, M. M.: The emergence of surface-based Arctic amplification, The Cryosphere, 3, 11-19, doi:10.5194/tc-3-11-2009, 2009.

Shindell, D. and Faluvegi, G.: Climate response to regional radiative forcing during the twentieth century, Nat. Geosci., 2, 294-300, doi:10.1038/ngeo473, 2009.

Shindell, D. T., Lamarque, J.-F., Schulz, M., Flanner, M., Jiao, C., Chin, M., Young, P. J., Lee, Y. H., Rotstayn, L., Mahowald, N., Milly, G., Faluvegi, G., Balkanski, Y., Collins, W. J., Conley, A. J., Dalsoren, S., Easter, R., Ghan, S., Horowitz, L., Liu, X., Myhre, G., Nagashima, T., Naik, V., Rumbold, S. T., Skeie, R., Sudo, K., Szopa, S., Takemura, T., Voulgarakis, A., Yoon, J.-H., and Lo, F.: Radiative forcing in the ACCMIP historical and future climate simulations, Atmos. Chem. Phys., 13, 2939-2974, doi:10.5194/acp-13-2939-2013, 2013.
Smith, S. J., Steven, J., Pitcher, H., and Wigley, T. M. L.: Global and regional anthropogenic sulfur dioxide emissions, Global Planet. Change, 29, 99-119, 2001.

Smith, S. J., Andres, R., Conception, E., and Lurz, J.: Historical sulfur dioxide emissions 1850-2000: Methods and results, PNNL Research Report, Joint Global Change Research Institute, 8400 Baltimore Avenue College Park, Maryland, 20740, 2004.

Taylor, K. E., Stouffer, R. J., and Meehl, G. A.: An overview of CMIP5 and the experiment design, B. Am. Meteorol. Soc., 93, 485-498, doi:10.1175/BAMS-D-11-00094.1, 2012.

Teng, H., Washington, W. M., Branstator, G., Meehl, G. A., and Lamarque, J.-F.: Potential impacts of Asian carbon aerosols on future US warming, Geophys. Res. Lett., 39, L11703, doi:10.1029/2012GL051723, 2012.

Trenberth, K. E. and Fasullo, J. T.: An apparent hiatus in global warming?, Earth's Future, 1, 19-32, doi:10.1002/2013EF000165, 2013.

Twomey, S. A., Piepgrass, M., and Wolfe, T. L.: An assessment of the impact of pollution on global cloud albedo, Tellus, 36, 356366, 1984. 